Katarzyna Laskowska

\title{
Ewolucja przestępczości zorganizowanej w Rosji
}

Keywords: organized crime, Russia

\section{Summary}

The article presents the development of the organized crime in Russia. The author has identified four stages of the evolution: period before the Bolshevik Revolution in 1917, then years 1917-1945, years 1945-1991 and finally period starting from 1991. She presents an opinion that the political events in each of these periods had big influence on shape of this kind of crime. The important role is connected with years before the October Revolution, because in this period the organized crime has emerged. The post - revolution period was also important, because in the first years after revolution gangs - so called „vory v zakonie" had good opportunities to develop. The real bloom of the organized crime took place after World War II, when the professional crime was replaced by the organized one. The reason for this evolution was the inefficiency of centralized economy, not limited power of the communist party apparatus and the mobility of criminals. After 1991 strong tights between business, politics and crime were established. This process made some of people very rich (illegally), but then their properties were legalized and the ruling class was corrupted. This process had great influence on emerging the new form of organized crime - the mafia.

The article shows that present criminal situation in Russia is a result of many historical events, complex social processes and complicated relations between citizens and government.

Korzeni i przyczyn rozwoju przestępczości zorganizowanej ${ }^{1} \mathrm{w}$ Rosji należy szukać w historii tego kraju. Chociaż jako zjawisko społeczne zrodziła się ona w XX w., to jej źródła sięgają wstecz nawet kilka wieków.

1 W kryminologii brak, jak dotychczas, jednej definicji przestępczości zorganizowanej. Na potrzeby niniejszych rozważań można w sposób uproszczony przyjąć, że polega ona przede wszystkim na popełnianiu różnorodnych przestępstw przez struktury przestępcze (grupy, związki, organizacje) o wysokim stopniu zorganizowania, dążące przy tym do maksymalizacji zysków przez stosowanie przemocy, gróźb jej użycia oraz wykorzystywanie powiązań korupcyjnych z organami władzy. 
Celem niniejszego opracowania jest przedstawienie procesu ewolucji przestępczości zorganizowanej w Rosji na tle przemian społeczno-polityczno-gospodarczych, zachodzących na przestrzeni wielu lat. Jednakże autorce, nie będącej historykiem (a kryminologiem badającym przestępczość), trudno było zachować dokładność historyczną w zakresie wszystkich ważnych wydarzeń i okresów w życiu państwa rosyjskiego. Zatem podział na okresy dokonany przez nią nie uwzględnia wielu wydarzeń historycznych występujących w omawianym czasie. Jest on umowny, obejmuje granice czasu istotne z punktu widzenia rozwoju przestępczości zorganizowanej. Do analizy wybrano dosyć rozległy okres, obejmujący lata poprzedzające rewolucję październikową 1917 r. aż po współczesne. Należy przy tym zaznaczyć, że zakres omawianej problematyki nie jest wyczerpujący ze względu na trudności w dostępie do źródeł i ich niekompletność.

\section{Rozwój przestępczości przed rewolucją październikową z 1917 r.}

Pierwsze materiały i źródła historyczne świadczące o funkcjonowaniu organizacji przestępczych, głównie złodziejskich, pochodzą z XV-XVI w. ${ }^{2}$ Kolejne wskazują na pojawienie się na przełomie XVII-XVIII w. niewielkich grup włóczęgów, zajmujących się drobnymi kradzieżami, rozbojami i żebractwem, którzy wraz z upływem czasu stanowili dosyć liczną grupę przestępców. To oni ukształtowali tradycje i prawa złodziejskiego świata przestępczego, nierzadko obowiązującego i przestrzeganego do dziś. Stali się założycielami stowarzyszenia przestępczego - „wory w zakonie” (przestępcy „koronowani”) ${ }^{3}$.

Od początku XIX w. w Rosji funkcjonowały też wyróżniające się pod względem zorganizowania bandy koniokradów, oszustów, szulerów karcianych i fałszerzy pieniędzy ${ }^{4}$. Jednakże nie wszystkie grupy przestępców zajmowały w świecie przestępczym jednakową pozycję. W ukształtowanej hierarchii kryminalnej wyróżniali się włóczędzy-żebracy. Byli to najczęściej ludzie, którzy zerwali z rodziną i społeczeństwem, prowadzili koczowniczy tryb życia, należeli do grupy przestępców (klanu, bractwa, stowarzyszenia). Kryteria te pozwalały uznać ich za prawdziwych przestępców. Mimo że włóczędzy nie osiągnęli znacznych sukcesów w rzemiośle przestępczym, to zawsze cieszyli się szacunkiem w tym specyficznym świecie. Najmniej szanowane grupy przestępców stanowiły te zajmujące się rozbojami i zabójstwami. Z kolei najliczniejszą kategorią były grupy złodziei o różnych specjalnościach, głównie złodziei kieszonkowych, kasiarzy i koniokradów. Najwyżej w hierarchii kryminalnej znajdowali się oszuści i fał-

\footnotetext{
2 Kriminołogija, red. W. N. Kudriawcew, W. J. Eminow, Moskwa 2005, s. 368.

${ }^{3}$ J. Kostjukowskij, Istorija rossijskoj organizovannoj priestupnosti, [w:] Dieviantnost' i socjalnyj kontrol w Rossiji (XIX-XX v.): tiendencji i socjołogičeskoje osmyslienije, red. J. I. Gilinskij, Sankt Petersburg 2000, s. 158.

${ }^{4}$ Ibidem, s. 158.
} 
szerze pieniędzy, ich działalność bowiem w sferze obrotu wekslami, akcjami, papierami wartościowymi i nielegalnych operacji wobec państwa wymagała sprytu $\mathrm{i}$ inteligencji ${ }^{5}$. Istnienie specjalizacji wymienionych grup oraz ich profesjonalizm świadczyły o ukształtowaniu się w Rosji przed 1917 r. przestępczości zawodowej $^{6}$.

Wraz z upływem czasu świat przestępczy w Rosji okrzepł, zjednoczył się, stał się bardziej monolityczny. Posiadł też siłę, by przeciwstawić się prawu i porządkowi publicznemu. Jego tradycje, prawa, profesjonalizm i język zakorzeniły się w środowisku całych pokoleń. Jednakże poważnemu rozwojowi świata przestępczego, zdaniem rosyjskich kryminologów ${ }^{7}$, przeszkadzały: brak rynku oraz silna wojskowa władza państwowa w Imperium Rosyjskim, „łamiąca grzbiety” potencjalnym konkurentom. Podkreślają oni, że przed 1917 r. w warunkach kryzysu politycznego i gospodarczego rozwijała się wykazująca już cechy zorganizowania przestępczość o charakterze handlowo-finansowo-przemysłowo-urzędniczym. Osiągając dochody z dostaw wojennych i spekulacji związanej z systemem kartkowym, przestępczość ta wpływała w pewien sposób na destabilizację kraju.

Warto zauważyć, że już na początku XX w. powstały w Rosji ukształtowane centra przestępczości. Były nimi przede wszystkim duże miasta: Sankt Petersburg, Moskwa, Kijów, Odessa, Rostów. W stolicy państwa - Sankt Petersburgu na początku XX w. rozwijała się przede wszystkim przestępczość pospolita i prostytucja. Odessa zaś jako miasto przyciągało przemytników, złodziei i przestępców posługujących się bronią. Rostów położony w centrum ziem kozackich przyciągał zbiegłych przestępców, którzy popełniali przestępstwa z użyciem przemocy. Wtedy też powstało powiedzenie „Rostów to ojciec, a Odessa to matka”, co było zgodne z ideologią włóczęgostwa, panującą w środowisku przestępczym ${ }^{8}$.

\section{Rozwój przestępczości w latach 1917-1945}

Rewolucja 1917 r. i następujące po niej wydarzenia w zasadniczy sposób zmieniły sytuację $\mathrm{w}$ przestępczym świecie Rosji. W pierwszych latach po rewolucji wielu zawodowych przestępców przebywających w zakładach karnych zostało wypuszczonych na wolność. Stało się tak w wyniku amnestii ogłoszonej przez Rząd Tymczasowy w 1917 r. Niektórzy z nich zatrudnili się nawet w organach CzeKa i milicji. W ten sposób złamali odwieczne złodziejskie prawa.

5 Ibidem, s. 163.

6 Szerzej na ten temat: A. I. Gurow, Profiesjonalnaja priestupnost'. Prošłoje i sovriemiennost', Moskwa 1990.; K. Laskowska, Zarys problematyki przestępczości zawodowej w Rosji, „Przegląd Policyjny” 2005, nr 1.

7 Osnovy borby sorganizovannoj priestupnostju, red. W. S., Owczinskij, W. J., Eminow, N. P. Jabłokow, Moskwa 1996, s. 167-168.

8 Zob. J. Kostjukowskij, op. cit., s. 163; A. Konstantinow, M. Dikselius, Banditskaja Rossija, Sankt Petersburg - Moskwa 1997, s. 42-43. 
W tym samym czasie byli żandarmi i oficerowie rozbitej Białej Armii jednoczyli się w zorganizowane bandy9.

Rosyjscy kryminolodzy na podstawie badań historyków podkreślają, że po rewolucji 1917 r. świat przestępczości zorganizowanej tworzyły nieduże grupy o charakterze kryminalnym, korzystające z politycznej ochrony. Na drogę przestępczą wchodziły nieraz także niektóre podziemne organizacje bolszewików, lewackich eserowców oraz ci, którzy znajdowali się na tyłach Armii Kołczaka, Denikina, Wrangla. Kryminalny charakter miała także działalność wielu niedużych liczebnie oddziałów powstańczo-partyzanckich, szczególnie tych, które znajdowały się pod wpływem i przywództwem przestępców ${ }^{10}$.

Jak uważa I. M. Dańszin, rozwojowi przestępczości zorganizowanej w tych latach sprzyjało dążenie grup przestępczych do osiągania korzyści przez użycie przemocy oraz zlikwidowanie przez państwo stosunków rynkowych w gospodarce ${ }^{11}$.

W latach dwudziestych XX w. zaobserwowano kryzys świata przestępczego, spowodowany walką o podział sfer wpływów. Ciągłe konflikty między różnymi grupami dyktowały potrzebę doskonalenia złodziejskich „praw”. W wyniku tego na bazie tradycji i obyczajów minionych czasów powstało jednolite „złodziejskie prawo", zgodnie z którym największe przestępcze autorytety nazywano „worami w zakonie”, tj. „koronowanymi”. Właśnie do tego okresu odnoszą się niektóre zasady działalności „koronowanych”, które są aktualne do dnia dzisiejszego ${ }^{12}$. Określały one, że „wor w zakonie” zajmuje szczególne miejsce w hierarchii liderów świata przestępczego w Rosji. „Koronowany” musiał być zawodowym przestępcą, wyniesionym do godności „koronowanego” przez zgromadzenie „worów” w nagrodę za przywiązanie do zasad i trwanie w tradycji utrwalonej przez złodziejski świat. To „koronowani” określali żywotność tradycji świata przestępczego. Niezależnie od miejsca pobytu utrzymywali stałe więzi między sobą, periodycznie spotykając się na złodziejskich zjazdach, tzw. „schodkach”. Podczas nich rozwiązywali wewnętrzne problemy świata złodziejskiego, dotyczące podziału terytorium i przestępczej działalności oraz czystości złodziejskich obyczajów ${ }^{13}$.

„Worowski zakon” rządził się swoimi prawami. Stanowiły one, że prawdziwy przestępca powinien poświęcać się i utrzymywać wyłącznie z działalności przestępczej. Nie może zakładać rodziny ani uczestniczyć w życiu społecznym

9 Kriminołogija, red. W. N. Kudriawcew, W. J. Eminow, Moskwa 2002, s. 399.
${ }^{10}$ Ibidem, s. 399.
${ }^{11}$ Kriminołogija, red. I. M. Dańszin, Charków 2003, s. 215.
${ }^{12}$ Kriminołogija, red. W. N. Kudriawcew, W. J. Eminow, Moskwa 2002, s. 399.
${ }^{13}$ Zob. szerzej: Rossijskaja kriminołogičeskaja encikłopiedija. Priestupnost' i borba s niej w poniatijach i kommentarijach, red. A. I. Dołgowa, Moskwa 2000, s. 119-120.; W.G. Grib, Protivodiejstvije organizovannoj priestupnosti, Moskwa 2001, s. 44. 
i politycznym kraju, nie powinien więc służyć w wojsku. Zobowiązany był natomiast wspierać moralnie i materialnie towarzyszy ze społeczności przestępczej. Powinien też pomagać im $\mathrm{w}$ trudnych sytuacjach, np. w razie problemów z policją lub podczas konfliktów między członkami grupy. Jego „wyrok” był w tym zakresie ostateczny ${ }^{14}$.

Istotny wpływ na kształtowanie się ideologii świata przestępczego miała sytuacja polityczna w kraju. W latach dwudziestych XX w. w rosyjskich zakładach karnych przebywało zdecydowanie więcej ofiar represji politycznych niż kryminalistów. Zaistniała sytuacja była konsekwencją ustanowienia reżimu dyktatorskiego z ogromną siłą organów represji, praktycznie wojskowego systemu zarządzania państwem $\mathrm{w}$ warunkach surowej dyscypliny i stosowania represji. Administracja zakładów karnych aprobowała znęcanie się „,złodziei” nad „politycznymi”, z których większość stanowili zwykli robotnicy i chłopi. Taka współpraca $\mathrm{z}$ administracją podzieliła „koronowanych”. Zaczął obowiązywać nowy kodeks, który pozwalał na częściową współpracę z pracownikami więzień ${ }^{15}$. Panująca wówczas w Rosji sytuacja, siłą rzeczy, przyczyniła się do spadku przestępstw popełnianych przez grupy przestępcze. Zdaniem O. W. Biełokurowa, stało się tak dlatego, że reżim podciął ekonomiczne korzenie przestępczości zorganizowanej. Doprowadziło to do ogromnego rozwarstwienia społeczeństwa i do sytuacji, w której okradanie biednego społeczeństwa było niemożliwe, a majątku państwowego pilnował aparat $\mathrm{NKWD}^{16}$. Świat przestępczy znów został zmuszony do walki o przetrwanie $\mathrm{w}$ miejscach pozbawienia wolności. Poważne rozwarstwienie w środowisku przestępczym nastąpiło w czasie Wielkiej Wojny Ojczyźnianej, kiedy znaczna jego część z własnej woli wzięła udział $\mathrm{w}$ walce $\mathrm{z}$ faszyzmem, pozostała poszła służyć okupantowi ${ }^{17}$.

\section{Rozwój przestępczości w latach 1945-1991}

W okresie powojennym aktywność przestępcza pierwszej i drugiej kategorii kryminalistów w znacznym stopniu przyczyniła się do wybuchu bandytyzmu $\mathrm{w}$ kraju ${ }^{18}$, który opanowano dzięki restrykcyjnemu systemowi prawa oraz sile organów ścigania i wymiaru sprawiedliwości. W okresie istnienia stalinowskiego totalitarnego państwa wszak nie mogły funkcjonować żadne organizacje prze-

${ }^{14}$ Zob. W. S. Razinkin, Organizovannaja priestupnost' w pieriod reform $w$ Rossiji, [w:] Organizovannaja priestupnost' - 3, red. A. I. Dołgowa, S. W. Djakow, Moskwa 1996, s. 76-82; szerzej W. S. Razinkin, „Vory w zakonie”. Kto oni?, „Priestuplenije i nakazanie” 1994, nr 10.; W. S. Razinkin, Vory w zakonie i priestupnyje kłany, Moskwa 1995.

${ }^{15}$ Kriminołogija, red. W. N. Kudriawcew, W. J. Eminow, Moskwa 2002, s. 399.

${ }^{16}$ O. W. Biełokurow, Organizovannaja priestupnost': istorija razvitja i formy projavlienija, Viestnik Moskovskowo Universiteta, Seria 11, „Pravo” 1992, nr 4, s. 55.

${ }^{17}$ Kriminołogija, red. W. N. Kudriawcew, W. J. Eminow, Moskwa 2002, s. 400.

${ }^{18}$ N. P. Jabłokow, Rassliedovanije organizovannoj priestupnoj diejatielnosti, Moskwa 2002, s. 11. 
stępcze. System represji skutecznie przyczynił się do destabilizacji świata przestępczego ${ }^{19}$.

Na funkcjonowanie świata przestępczego miały też wpływ reformy podjęte w latach chruszczowowskiej „odwilży”. W ich wyniku nastąpiły bowiem poważne zmiany w rosyjskiej polityce karnej. Polegały one na jej liberalizacji, ale nie wynikały z realnej oceny sytuacji przestępczej w kraju. Na podstawie przedwczesnych i bezpodstawnych twierdzeń o znacznym spadku przestępczości w państwie, a szczególnie o likwidacji jej zorganizowanych form, niemalże zaniechano $\mathrm{z}$ nią walki ${ }^{20}$.

W wyniku tego przestępcy poczuli się bezkarni. Zaczęła się intensywnie odradzać przestępczość ${ }^{21}$. Utworzył się specyficzny świat przestępczy, w którym pojawili się liderzy, organizatorzy, autorytety przestępcze. Propagowali oni i upowszechniali złodziejskie prawo ${ }^{22}$.

Sytuacja ta wpłynęła na wzrost przestępczości w gospodarce. Ponieważ przemysł państwowy nie zaspokajał stale rosnących potrzeb społeczeństwa na towary powszechnego użytku, uchwalono więc prawo zezwalające na istotne rozszerzenie przemysłowej działalności spółdzielni. Niestety, państwo nie zdołało zabezpieczyć przedsiębiorstw w niezbędne ilości surowców, ani nie stworzyło odpowiedniej kontroli finansowej i gospodarczej ich działalności. Umożliwiło to rozwój przestępczości skierowanej na osiąganie korzyści majątkowych, polegającej na nierzetelnym dokumentowaniu wykonania planów produkcyjnych, nadużywaniu stanowisk służbowych, łapownictwie. W związku z tym $\mathrm{w}$ celu realizacji zapotrzebowania społecznego znaczną część produkcji spółdzielcy prowadzili w nielegalnych cechach z surowców zdobytych „na boku” i dystrybuowanych nielegalnymi kanałami. $\mathrm{W}$ taki to sposób osoby związane $\mathrm{z}$ działalnością cechów (zw. „cechowikami”) otrzymały możliwości bogacenia się w sposób nielegalny. Do spółdzielni przyciągały one chętnych chcących zalegalizować „brudne” pieniądze, osoby wcześniej karane, traktujące spółdzielnię jako przykrywkę działalności przestępczej ${ }^{23}$. W ten sposób powstały struktury tzw. gospodarki „cienia” („szarej” gospodarki) ${ }^{24}$.

${ }^{19}$ W. W. Mierkuszin, Borba s transnacjonalnoj organizovannoj priestupnostju, Mińsk 2003, s. 40.

${ }^{20}$ Zdaniem O. G. Cyplakowej, był to rezultat „przyspieszonej” walki z powojenną przestępczością. Zob. O. G. Cyplakowa, Organizovannaja priestupnost' $w$ Rossiji: faktory razvitja i miery socjalnovo kontrolja, [w:] Organizovannaja priestupnost' w Rossiji: tieorija i riealnost', red. J. I. Gilinskij, Sankt Petersburg 1996, s. 57.

${ }^{21} \mathrm{~J}$. W. Topilskaja uważa, że to właśnie w latach 60 . zaczęły powstawać grupy przestępcze o wysokim poziomie zorganizowania. Zob. J. W. Topilskaja, Organizovannaja priestupnost', Sankt Petersburg 1999, s. 27.

${ }^{22}$ I. M. Dańszin, op. cit., s. 216.

${ }^{23}$ Ibidem, s. 216-217.

${ }^{24} \mathrm{O}$ mechanizmie tej gospodarki bliżej: J. Błuwsztejn, W. Justickij, Przestępczość zorganizowana w społeczeństwie postkomunistycznym. Mity i rzeczywistośc, [w:] Kryminologiczne i prawne aspekty przestępczości zorganizowanej, red. A. Marek, W. Pływaczewski, Szczytno 1992, s. 153. 
Działalność ta zwróciła uwagę przestępców, zajmujących się dotąd kradzieżami, oszustwami, napadami, czyli głównie przestępstwami związanymi z osiąganiem korzyści przy użyciu przemocy. „Cechowiki” zostali więc nakłonieni do „współpracy”. Za pomocą gróźb, szantażu, zmuszono ich do systematycznego przekazywania części nielegalnych dochodów. Wkrótce doszło jednak do kompromisu, który uwzględnił interesy obu grup przestępców. Otóż uczestnicy podziemnej gospodarki zaczęli wykorzystywać wpływy autorytetów świata przestępczego do zastraszania i usuwania swoich konkurentów, a także do ochrony i dystrybucji nielegalnie wyprodukowanych towarów. Ci drudzy zostawali wspólnikami pierwszych, wnosząc do biznesu przestępczego własne, nabyte niezgodnie z prawem środki, wspierając w ten sposób wzrost wspólnej produkcji i dochodów ${ }^{25}$.

Ta symbioza stała się przyczyną powstania wielu grup przestępczych w różnych dziedzinach gospodarki, we wszystkich regionach państwa. Ich liderzy i organizatorzy opracowywali taktykę przystosowania własnej działalności do warunków istniejącego wówczas systemu biurokratycznego. Uznali bowiem za ważne znalezienie odpowiednich osób, pod których opieką („kryszą”) można by bezpiecznie funkcjonować. I takie osoby znajdowali w szeregach sprzedajnego aparatu partyjno-państwowego, gospodarczego, przedstawicieli organów ścigania i wymiaru sprawiedliwości. Szczególnie intensywny rozwój związków o charakterze korupcyjnym nastąpił i był widoczny w okresie rządów zarówno Nikity Chruszczowa, jak i Leonida Breżniewa. Równolegle zmieniała się struktura wewnętrzna grup przestępczych. Wśród ich uczestników nastąpił wyraźny podział na liderów, organizatorów i wykonawców, wzrósł poziom ich zwartości, hierarchiczności organizacyjnej, konspiracji i wyposażenia technicznego ${ }^{26}$. Przestępczość zawodowa przekształciła się w przestępczość zorganizowaną.

Jednakże $\mathrm{w}$ państwie rosyjskim nie zauważano lub nie chciano widzieć zmian odbywających się w świecie przestępczym. I. M. Dańszin przypomina, że przez lata $\mathrm{w}$ świadomości społecznej funkcjonowało przekonanie o braku w Związku Radzieckim przestępczości zorganizowanej. Sygnały o niej oceniane były jak mit. Lecz życie zmusiło do uznania smutnej rzeczywistości. Nastąpiło to dopiero w końcu lat 80., podczas „pieriestrojki” zainicjowanej przez Michaiła Gorbaczowa. W tym czasie jednakże zorganizowana przestępczość opanowała już wszystkie republiki związkowe ${ }^{27}$.

W okresie rządów M. Gorbaczowa zachęcano społeczeństwo do tworzenia prywatnych przedsiębiorstw w formie spółdzielni. Podstawy ku temu stworzyła ustawa o kooperacji z 1988 r. Spowodowała ona jednak żywiołowy niekontrolowany proces gromadzenia kapitału pochodzącego ze środków państwowych

\footnotetext{
${ }^{25}$ I. M. Dańszin, op. cit., s. 217-218.

${ }^{26}$ Ibidem, s. 218.

${ }^{27}$ Ibidem, s. 218.
} 
przekazywanych następnie do spółdzielni, a ściślej do sektora prywatnego, nierzadko mającego charakter nielegalny. Ten moment, zdaniem rosyjskich kryminologów ${ }^{28}$, uznaje się za bardzo ważny w historii rozwoju przestępczości zorganizowanej, bo nastąpiło wówczas połączenie „szarego” kapitału zgromadzonego w czasach reżimu totalitarnego z młodym, agresywnym kapitałem gangsterskim.

Tak więc pod koniec lat 80 . w społeczeństwie funkcjonowały wysoko zorganizowane ugrupowania przestępcze, złożone ze skorumpowanych urzędników państwowych i działaczy partyjnych powiązanych ze środowiskiem przestępczym. W rezultacie nieprzemyślanych i pseudogospodarczych reform w ręce przestępczości zorganizowanej dostał się ogromny kapitał ${ }^{29}$. Jak zauważa V. Coulloudon, radzieckie struktury przestępcze całkowicie zintegrowały się z władzą państwową ${ }^{30}$. Można zatem powiedzieć, że gigantyczny aparat państwowy nie tylko zezwalał na działania przestępcze, ale zachęcał, ułatwiał i ochraniał je, ponieważ sam z nich korzystał.

Wraz z upływem czasu przestępczość zorganizowana coraz bardziej przenikała w sfery gospodarki, które bezpośrednio były związane z zaopatrywaniem społeczeństwa w niezbędne towary. Brak wpływu państwa na kształtowanie cen doprowadził do masowych nadużyć i ukrywania dochodów. Tworzyło to nowe warianty działalności przestępczej ${ }^{31}$. Uważa się, że właśnie wówczas powstały mocne fundamenty mafii $\mathrm{w}$ jej obecnej postaci, gdyż od samego początku rosyjski biznes był mocno związany z przestępczością. Państwo z jednej strony wspomagało tę sytuację poprzez politykę podatkową, niedoskonałości prawa, sprzeczne dekrety i postanowienia, reformy pieniądza, gry z kursem rubla, prywatyzacją $^{32}, \mathrm{z}$ drugiej zaś strony - zaostrzenie prawa i niestabilność państwa popychały biznes w kierunku jak najszybszego wzbogacenia się (lecz nie rozwoju ekonomicznego), powrotu do „szarej” gospodarki. U biznesmenów i przestępców wywoływało to potrzebę zabezpieczenia się przez „wejście do struktur władzy", która gwarantowała bezkarne łamanie prawa ${ }^{33}$. Taka sytuacja spowodowała niespotykany dotąd poziom korupcji i przeniknięcie przestępców do instytucji państwowych.

W ocenie O. W. Biełokurowa, przeplatanie się różnych form przestępczości zorganizowanej (politycznej, kryminalnej, gospodarczej) było tragicznym rezul-

\footnotetext{
${ }^{28}$ Kriminołogija, red. W. N. Kudriawcew, W. J. Eminow, Moskwa 2002, s. 402-403.

${ }^{29}$ A. W. Gyske, Sovriemiennaja rossijskaja priestupnost' i probliemy biezopasnosti obščiestva. Političieskij analiz, Moskwa 2000, s. 89.

${ }^{30}$ V. Coulloudon, Mafia sowiecka, tł. M. Kasprowska-Pognon, Warszawa 1993, s. 7.

${ }^{31}$ A.W. Gyske, op. cit., s. 89.

${ }^{32}$ Proces ten określano „upaństwowieniem mafii”. Zob. Kriminołogija, red. W. N. Kudriawcew, W. J. Eminow, Moskwa 2005, s. 376.

${ }^{33}$ Słusznie porównywano byłe państwo komunistyczne do mafiosa i terrorysty numer jeden. Zob. E. Pływaczewski, Węzłowe problemy przestępczości zorganizowanej w Polsce, [w:] Policja polska wobec przestępczości zorganizowanej, red. W. Pływaczewski, J. Świerczewski, Szczytno 1996, s. 17-18.
} 
tatem stopniowego naruszania w połowie lat 80. fundamentów gospodarczych ustroju socjalistycznego, zbudowanych w latach 30. Powiązania tych form, zrastanie się ich od początku lat 90., spowodowały powstanie nowego etapu rozwoju tego zjawiska ${ }^{34}$.

\section{Przemiany w przestępczości zorganizowanej po $1991 \mathrm{r}$.}

Rozpad ZSRR w 1991 r. i w jego konsekwencji zerwanie więzi ekonomicznych z byłymi republikami, osłabienie kontroli granicznych, niestabilna sytuacja gospodarcza i polityczna kraju, przejście ogromnych zasobów w prywatne ręce, spowodowały, że przestępczość zorganizowana w Rosji weszła na nowy jakościowo poziom.

Początek lat 90. rozpoczął się od swoistej wojny pokoleń między „starymi” przestępcami a „młodymi”, którzy odmawiali przyjęcia ascetycznego, złodziejskiego stylu życia i nie uznawali autorytetów przestępczych starej generacji ${ }^{35}$. Doszło więc do walk między grupami przestępczymi, w rezultacie których wielu liderów poniosło śmierć.

Ponadto w tym czasie, głównie w dużych miastach Rosji, powstało wiele grup o charakterze narodowościowym i religijnym (określanych etnicznymi), wywodzących się zza Bajkału. Stało się to przyczyną ich konfliktów z grupami „słowiańskimi”. Grupy o charakterze etnicznym (ormiańskie, gruzińskie, czeczeńskie, tatarskie), osiągając coraz większe wpływy w świecie przestępczym i rozwijając swą działalność, poważnie im zagrażały.

Pomimo walk między grupami świat przestępczy zachowywał dużą mobilnośćc ${ }^{36}$. Znaczny udział społeczeństwa w działalności przestępczej powodował powstawanie nowych grup, które podlegały kolejno procesowi podziału i integracji. Ich bardzo dobra sprawność organizacyjna przekładała się też na łatwość dostosowywania się do zmieniających się warunków gospodarczo-politycznych. Należy bowiem pamiętać, jak zauważa W. W. Łuniejew, że przestępczość mająca aktywny rynkowy charakter stale szuka i zapełnia nowe, pozbawione kontroli lub słabo kontrolowane sfery i nisze e $^{37}$.

Na podstawie analizy działalności grup przestępczych A. N. Basałajew wyróżnił kilka etapów rozwoju przestępczości zorganizowanej w Rosji w latach 90.

${ }^{34}$ O. W. Biełokurow, op. cit., s.57.

${ }^{35}$ J. Kostjukowskij, op. cit., s. 171.

${ }^{36}$ Sprzyjała temu mentalność „człowieka radzieckiego”, której nie tak łatwo się pozbyć. Charakteryzowała ją samowola, pogarda dla prawa, niska kultura prawna oraz pokora wobec przywódcy, autorytetu. Zob. J. Błuwsztejn, I. Bazylew, Problem przestępczości zorganizowanej na Litwie, [w:] Kryminologiczne i prawne aspekty przestępczości zorganizowanej, red. A. Marek, W. Pływaczewski, Szczytno 1992, s. 150; Kriminołogija, red. W. N. Burłakow, N. M. Kropacziow, Sankt Petersburg 2002, s. 385.

${ }^{37}$ W. W. Łuniejew, Priestupnost' w Rossiji pri pierechodie ot socjalizma k kapitałizmu, „Gosudarstvo i Pravo" 1998, nr 5, s. 53. 
Jego zdaniem, najpierw przestępcy dokonywali kradzieży, bogacili się dzięki możliwościom i pomocy środowiska przestępczego oraz łączyli się w zwarte grupy w celu maksymalizacji osiąganych dochodów i ucieczki od odpowiedzialności karnej. Następnie dokonywali akumulacji dużych środków finansowych pozwalających na organizację i utrzymanie grupy przestępczej, na zabezpieczanie i wzrost osiąganych dochodów, podtrzymywanie dyscypliny w grupie oraz korumpowanie i posiadanie powiązań z urzędnikami gwarantującymi bezpieczną działalność grupy. Na kolejnym etapie przestępcy gromadzili dostateczne środki finansowe w kraju i za granicą w celu nabycia przedsiębiorstw, banków, nieruchomości, a także wykorzystywali je na korumpowanie i utrzymywanie w celach lobbingowych kontaktów z przedstawicielami organów państwowych różnego szczebla. Następnie przywódcy grup przestępczych „legalizowali się”, przenikając w struktury organów władzy i podporządkowując gospodarkę realizacji interesów przestępczych ${ }^{38}$.

Niektórzy spekulowali, że kolejny etap będzie nazywał się kolumbizacja ${ }^{39}$. Można pokusić się o takie stwierdzenie, gdyż od lat 90. rozpoczęła się szeroka integracja rosyjskiej przestępczości zorganizowanej z systemem ogólnoświatowym.

W tym miejscu warto podkreślić, że przez lata swojej działalności grupy przestępcze dążyły przede wszystkim do realizacji dwóch głównych celów: osiągania maksymalnych zysków i zdobycia wpływu na władzę. Ogromne dochody uzyskiwały dzięki wielu nielegalnym transakcjom, wśród których wyróżniały się: handel narkotykami, bronią, materiałami wybuchowymi, prostytucja, wymuszenia, hazard ${ }^{40}$. Dzięki temu grupom udało się przejąć kontrolę nad wieloma gałęziami handlu, produkcji, transportu, małymi, średnimi i dużymi przedsiębiorstwami oraz operacjami finansowymi.

Następnym celem było zdobycie władzy lub chociażby wpływu na nią. Stąd też wielu liderów przestępczych po zgromadzeniu ogromnego kapitału dążyło do udziału w życiu politycznym państwa przez wchodzenie do organów władzy różnego szczebla ${ }^{41}$. Cel ten był osiągany w wyniku stosowania terroru kryminalnego (zabójstwa na zlecenie, branie zakładników, przestępstwa z użyciem broni palnej i materiałów wybuchowych) wobec niewygodnych, nieposłusznych lub niepokornych urzędników, przedsiębiorców, bankierów ${ }^{42}$, jak również przez ko-

\footnotetext{
${ }^{38}$ A. N. Basałajew, Etapy razwitija organizovannoj priestupnosti, [w:] Organizovannaja priestupnost' - ugroza kulturie i dierżavnosti Rossiji, red. P. P. Głuszczenko, J. A. Łukicziew, Sankt Petersburg 1998, s. 97.

${ }^{39}$ S. M. Inszakow, Kriminołogija, Moskwa 2000, s. 202.

${ }^{40}$ Szerzej na ten temat zob. K. Laskowska, Rosyjskojęzyczna przestępczość zorganizowana. Studium kryminologiczne, Białystok 2006, s. 167-205.

${ }^{41}$ Zob. W. G. Grib, op. cit., s. 31; Sostojanije priestupnosti w Rossijskoj Fiedieracji i jejo dołgosrocznyj prognoz, red. P. G. Ponomariew, Moskwa 1998, s. 7-8.

${ }^{42}$ Zob. Kriminogiennaja situacija w Rossiji na rubieże XXI vieka, red. A. I. Gurow, Moskwa 2000, s. 24.
} 
rumpowanie przedstawicieli aparatu władzy oraz organów ścigania i wymiaru sprawiedliwości.

Realizacja obu celów doprowadziła do powstania w Rosji najwyższej formy organizacyjnej przestępczości zorganizowanej - mafii. Było to możliwe także dlatego, że w Rosji od dawna występowało środowisko sprzyjające jej rozwojowi. Tworzyły je zakorzeniona w historii tego państwa korupcja, biurokratyzacja, powiązania przestępczości z władzą i społeczna akceptacja takich działań. Dlatego fenomen współczesnej przestępczości zorganizowanej nie może być poddawany analizie w oderwaniu od tych zjawisk.

Jak wynika $\mathrm{z}$ rozważań, przestępczość zorganizowana bierze początek w różnorodnych formach organizacyjnych przestępców zawodowych. Jednakże w odróżnieniu od przestępczości zawodowej, przestępczość zorganizowana jest bardziej złożona, różnorodna, posiada strukturę i hierarchię, łatwiej przystosowuje się do zmieniających się warunków społeczno-gospodarczych i nie może funkcjonować bez związków ze skorumpowanymi urzędnikami, czym stwarza poważne zagrożenie dla państwa i społeczeństwa.

Konkludując, początki rozwoju przestępczości zorganizowanej w Rosji sięgały, co prawda, kilka wieków wstecz, to jednak prawdziwych korzeni i źródeł należy upatrywać w pierwszych latach istnienia Związku Radzieckiego. Pierwszy okres związany był z funkcjonowaniem najpierw band, a potem organizacji „,worów w zakonie". Ich przestępcza działalność, zmierzająca głównie do zdobywania korzyści majątkowych, nie osiągnęła jeszcze w tym czasie wysokiego poziomu organizacji przestępczych. Kolejny etap charakteryzował rozwój systemu partyjno-administracyjnego, w którym przestępczość zaczęła wykazywać powiązania z przedstawicielami różnych szczebli władzy, obejmując w ten sposób cały kraj. Dla rozwoju przestępczości zorganizowanej decydujący okazał się współczesny etap związany z rozpadem Związku Radzieckiego i przemianami systemu gospodarczo-politycznego. Dokonujące się przemiany społeczno-ekonomiczne doprowadziły do wzrostu przestępczości. Na tym etapie przestępczość zorganizowana prezentowała sobą najbardziej współczesne formy. Przybrała ogromne rozmiary, rozszerzyła sfery swojej działalności i przekroczyła granice państwa rosyjskiego. 